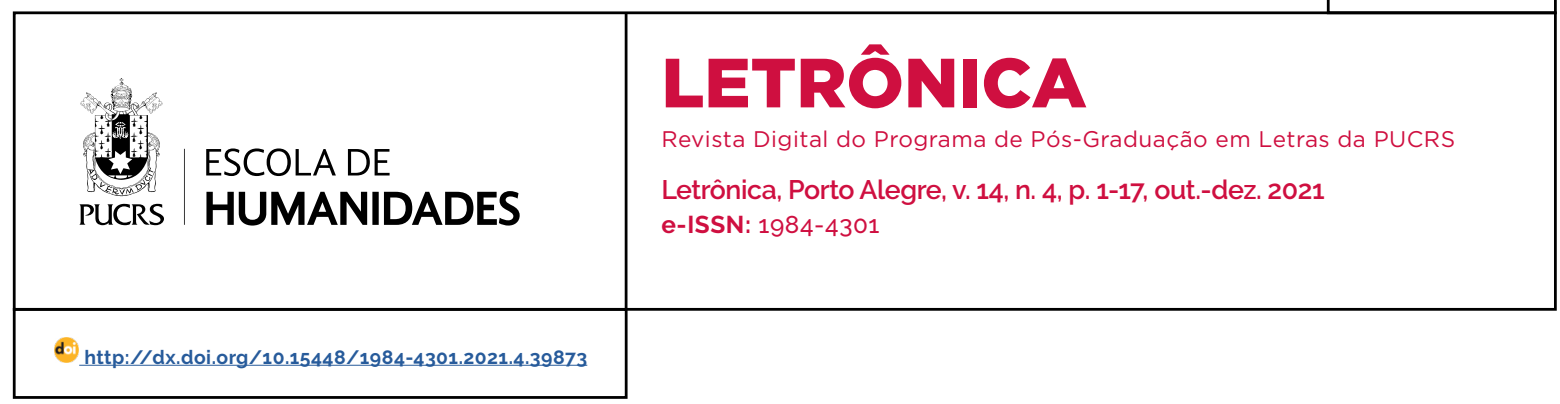

SEÇÃO: ARTIGOS

\title{
Os sentidos do "novo mundo" nas publicidades da Latam Airlines sobre a pandemia no Facebook
}

\author{
The meanings of the "novo mundo" in Latam Airlines advertising about the pandemic \\ on Facebook
}

\section{Gabriella Cristina Vaz Camargo ${ }^{1}$}

orcid.org/0000-0002-2499-3460

gabriellavazcamargo@gmail.com

\section{Nathan Bastos de \\ Souza ${ }^{2}$ \\ orcid.org/0000-0003-1560-2867 \\ nathanbastos600@gmail.com}

Recebido em: 10 jan. 2021 Aprovado em: 9 set. 2021. Publicado em: 27 jan. 2022.
Resumo: O objetivo deste artigo é estudar os sentidos do signo "novo mundo" a partir de três posts publicitários da Latam Airlines, publicados em sua página do Facebook. O recorte privilegiou os posts com imagem e texto em que aparecia materialmente o signo "novo mundo", em uma amostra discursiva tomada entre os meses de março e setembro de 2020. Apresentamos uma seção teórica em que discutimos o signo ideológico conforme Volóchinov (2017) e uma seção em que tratamos da questão do enunciado concreto e sua abordagem metodológica a partir do Círculo de Bakhtin. A análise relaciona os três posts publicitários com momentos distintos de compreensão da pandemia de Coronavirus pela sociedade: um "novo mundo" em emergência, no primeiro, em consolidação, no segundo; e como já dado no terceiro post. Consideramos, por fim, que o "novo mundo" que a Latam constrói em seu discurso é sua forma de enfrentamento da pandemia e sua estratégia ideologicamente construida para vender passagens, que ocorre simultaneamente à retomada das atividades econômicas da sociedade.

Palavras-chave: Signo ideológico. Avaliação social. Discurso publicitário.

Abstract: The aim of this paper is to study the meanings of the sign "novo mundo" from three advertising posts of Latam Airlines, published on its Facebook page. The clipping privileged the posts with image and text that the sign "novo mundo" was materialized, in a discursive sample taken between the months of March and September 2020. We present a theoretical section that we discuss the ideological sign according to Volóchinov (2017) and a section in which we deal with the question of the concrete utterance and its methodological approach from the Bakhtin Circle. The analysis links the three advertising posts with different moments of understanding of the Coronavirus pandemic by society: a "novo mundo" in emergence, in the first, a "novo mundo" in consolidation, in the second; a "novo mundo" as already given in the third. Finally, we consider that the "novo mundo" that Latam builds in its discourse is its way of coping with the pandemic and its ideologically constructed strategy to sell tickets, which occurs simultaneously with the resumption of society's economic activities.

Keywords: Ideological sign. Social evaluation. Advertising discourse. 


\section{Introdução}

Expressões com ideia de novidade, durante o ano de 2020, se tornaram comuns no vocabulário social em todo o mundo. A mídia a cada dia, desde a aparição dos primeiros casos, na China, de um "virus novo", em seguida chamado "novo coronavírus", instaurou essa ideia de novidade com a emergência de uma situação sanitária globalmente experimentada. Um vírus que começou a circular ainda em 2019 obrigou a uma "nova normalidade", assim, a expressão "novo normal" se sedimentou e tivemos nosso círculo social brutalmente diminuído ao básico. No início, a "quarentena" era a única saida que os órgãos sanitários indicavam como eficaz para "achatar a curva" de novos contágios desse virus que ceifou milhares de vidas em todo o planeta. Esse "novo normal" impôs até mesmo uma "nova estética" para os rostos humanos, agora em toda parte obrigatoriamente protegidos (semicobertos) pelo uso de máscaras. ${ }^{3}$

Essa semântica da novidade, com expressões como "novo normal", parece em si inaugurar uma anterioridade em relação a que se diferencia. Destarte, haveria um "velho normal", um "antigo normal" em contraponto a esse "novo". A expressão "novo normal" coloca em circulação uma oposição fundamental, conforme Santos e Baronas (2020), entre aquilo que é urgente e o que pode ser visto como ultrapassado ou insuficiente para os problemas do agora.

Como contribuição ao entendimento do sentido de uma dessas expressões de novidade - nas quais se conjugam um discurso sobre o passado e sobre as práticas ultrapassadas - estudamos neste artigo os sentidos de "novo mundo" como um signo ideológico no contexto da publicidade da empresa aérea Latam Airlines. ${ }^{4}$ Esse signo emerge na publicidade da Latam como uma forma de construir ideologicamente um discurso de enfrentamento ao virus.

Para lograr esse objetivo, estudamos três posts publicitários ${ }^{5}$ de momentos diferentes da pandemia, entre março e setembro de 2020, todos publicados na conta oficial no Facebook da empresa, em que figura por escrito o signo "novo mundo". Com base nessas amostras discursivas, discutimos o desenvolvimento do sentido do signo "novo mundo" a partir de três momentos temporais e de compreensão do virus: 6 um "novo mundo" em emergência, no começo "oficial" da pandemia no Brasil; um "novo mundo" em consolidação, com a fase mais ou menos próxima à metade do ano de 2020; um "novo mundo" como já dado, no último quadrimestre do ano.

Para traçar esse percurso de compreensão organizamos este artigo em uma seção a respeito da noção de signo ideológico, com Volóchinov (2017), uma seção metodológica de abordagem do enunciado conforme Bakhtin (2011a), Medviédev (2012) e Volóchinov (2019) e uma seção analítica em que compreendemos o signo ideológico "novo mundo" na publicidade da Latam Airlines no Facebook.

\section{Signo ideológico}

Para pensarmos a ideologia e sua materialização partiremos da reflexão de Volóchinov (2017) que defende uma abordagem marxista da filosofia da linguagem ancorada em uma filosofia do signo ideológico. No bojo desse projeto, a ideia de signo ideológico aparece como a materialização na linguagem da ideologia, de modo que nada penetra esse universo como uma realidade

\footnotetext{
3 Destacamos como um esforço para o debate social em torno do tema da pandemia realizado pela equipe de curadoria linguística do INFORMA-SUS-UFSCar a Enciclopédia Discursiva da COVID-19, um projeto de extensão coordenado pelos professores Fernanda Castelano Rodrigues e Roberto Baronas, do Departamento de Letras, da Universidade Federal de São Carlos. Essa enciclopédia conta com diferentes verbetes, como "novo normal", "testar positivo", "achatar a curva", "linha de frente", "pandemia". Para mais informações e acesso aos verbetes, consultar: https://bit.ly/2KfGzEe. Acesso em: 17 set. 2021.

4 A Latam Airlines Group é uma companhia aérea chileno-brasileira, que foi criada com a fusão entre a companhia LAN Airlines, chilena, e a companhia TAM Linhas Aéreas, brasileira. O lançamento oficial da marca, bem como suas novas cores e logo, aconteceu em 2015 e. segundo seu site, é a maior empresa aérea da América Latina. O histórico da LATAM pode ser consultado em seu site oficial: https://www. latam.com/pt_br/conheca-nos/sobre-nos/historia/. Acesso em: 12 dez. 2020.

5 Neste estudo, entendemos como gênero discursivo post publicitário o enunciado verbal e sua legenda, que foram coletados por meio da ferramenta PrintScreen, bem como a disposição desses elementos na tela. Dessa maneira, o termo "post publicitário" designa, então, o print que contempla enunciado e legenda.

6 Entendemos que os momentos temporais são análogos a momentos de compreensão do vírus e da pandemia, inclusive socialmente.
} 
material ou social, como um corpo físico ou um instrumento. Cada produto ideológico que aparece na forma de signo entra para a linguagem refletindo e refratando outra realidade, externa em relação ao corpo físico ou instrumento. Dito de outro modo, tomando os exemplos clássicos utilizados pelo autor: a foice e o martelo como instrumentos de produção são objetos do mundo em si, todavia são diferentes, quando aparecem na bandeira da União Soviética. O pão e o vinho, como alimento e bebida alcoólica, respectivamente, existem no mundo como produtos de consumo, mas dentro dos ritos religiosos do catolicismo transformam-se em parte de um sacramento, tornam-se signos ideológicos.

Para esses dois casos, a ideia de signo ideológico somente aparece quando esses objetos de trabalho ou produtos de consumo adquirem "uma significação que ultrapassa os limites de sua existência particular" (VOLÓCHINOV, 2017, p. 93). Desse modo, o pão e o vinho como partes de um ritual religioso se transformam em signo ideológico porque comportam a capacidade simultânea de ser parte de uma realidade e de refletir e refratar outra realidade. Quanto à especificidade do signo ideológico, além de ser um reflexo, é uma parte material da realidade. Nesse sentido, o signo é externo, vive do contato entre os sujeitos em sociedade. Sobre o signo ideológico, Volóchinov (2017, p. 94) afirma que:

Qualquer fenômeno ideológico sígnico é dado em um material: no som, na massa física, na cor, no movimento do corpo e assim por diante. [...] O signo é um fenômeno do mundo externo. Tanto ele mesmo, quanto todos os efeitos por ele produzidos, ou seja, aquelas reações, aqueles movimentos e aqueles novos signos que ele gera no meio social circundante, ocorrem na experiência externa.

Do ponto de vista do autor, o signo aparece no mundo como uma parte de sua materialidade, inscrita nos diversos suportes possiveis. Assim, o signo é a parte material da ideologia, uma forma de seu aparecimento no mundo exterior.

Ademais, Volóchinov (2017, p. 95) rechaçando as hipóteses psicologicistas e idealistas que colocavam na consciência o trabalho da ideologia, afirma que essas correntes ignoram que "a compreensão pode ser realizada apenas em algum material signico" e que a consciência só existe efetivamente quando "encarnada em material signico". O autor completa sua crítica ao afirmar que a compreensão responde aos signos por meio de outros signos.

Isso significa que existem elos de compreensão de signo a signo, formando uma cadeia de criação e compreensão ideológica ininterrupta. O corpus aqui analisado possibilita compreendermos alguns desses elos em questão. Como, por exemplo, o signo "novo mundo" nas publicidades da Latam que promove sentidos relacionados à pandemia - de que um mundo com novas normas, regras e recomendações em surgimento - porque tem sido utilizado também em outras esferas de comunicação, como a jornalística, por meio de gêneros discursivos diversos. Assim, são estabelecidos elos entre os signos, seja na mesma esfera e mesmo gênero ou não. Nessa esteira se desenvolve uma cadeia interativa entre as consciências, sumamente social e ali se encontra o nascedouro dos novos signos. As consciências, colonizadas pelos signos, só existem porque são preenchidas de conteúdo ideológico advindo do contato social entre os sujeitos.

O fato ideológico tem, assim, sua real existência apenas como "um material sígnico especíico, que é social, isto é, criado pelo homem" (VOLÓCHINOV, 2017, p. 96). Entretanto, não basta apenas que haja dois Homo sapiens; a emergência dos signos exige que estejam organizados socialmente. A conclusão a que se chega, a contrapelo das perspectivas psicologicistas e idealistas que entendiam a consciência como uma espécie de terra de ninguém a que se direcionavam os problemas sem resolução é que, nas palavras de Volóchinov (2017, p. 97) "a consciência individual é um fato social e ideológico". Nessa perspectiva, os fenômenos ideológicos somente podem existir por meio dos signos que são, de fato, uma realidade objetiva. Dito de outro modo, conforme Volóchinov (2017, p. 98), "a existência de um signo não é nada mais que uma materialização" da comunicação social. 
O autor refere-se às possibilidades materiais que os signos podem cobrar para existir - no som, na massa física, na cor, como mencionamos anteriormente - mas reserva também lugar destacado ao problema da palavra. Se, por um lado, a palavra é um fenômeno ideológico por excelência, já que as questões ideológicas podem ser com maior facilidade explicadas por meio da materialidade da palavra, por outro, a palavra é um signo neutro. Se outros materiais são especializados em comunicar o conteúdo ideológico de campos específicos, a palavra serve a todos e qualquer um, por isso seu caráter neutro como signo. Isto é, a mesma palavra pode assumir nos diferentes campos da criação ideológica em que circula os mais diversos matizes significativos, de uma maneira que seu sentido difere ao sabor da relação estabelecida entre os sujeitos socialmente organizados em que estiver em discussão. Uma terceira particularidade da palavra é que "se tornou material sígnico da vida interior" (VOLÓCHINOV, 2017, p. 100), desse modo, a consciência já desperta envolta na palavra. Assim, atravessa todos os processos compreensivos e de criação ideológica, nada escapa à natureza irrevogável da palavra como acompanhamento ou apoio aos demais signos, embora não seja capaz de substituir nenhum dos outros tipos.

A compreensão de cada novo signo nesse universo pode ser entendida nos seguintes termos: "em torno de todo signo ideológico se formam como que círculos crescentes de respostas e ressonâncias verbais" (VOLÓCHINOV, 2017, p. 101). Esse comportamento em círculo crescente que gera respostas aos signos já existentes está sempre acompanhado pela palavra, em toda compreensão e avaliação, lá está a palavra. É possivel afirmar, portanto, que além de estabelecer um elo de sentidos, os signos também possuem caráter responsivo, respondem e suscitam respostas de outros signos.

O signo ideológico "novo mundo" nos posts publicitários da Latam, conforme veremos na análise, responde a um discurso da semântica da novidade, um "novo" que se relaciona tanto ao vírus, quanto a um modo de viver, de se comportar e, sobretudo, de viajar. Se há um novo virus que obriga os individuos a repensarem suas atividades rotineiras e a maneira como as realizam, em consequência surge um "novo mundo", novos sentidos, que são materializados por meio do signo ideológico.

Dessa perspectiva, conforme o Volóchinov (2017), o estudo dos signos deve se realizar antes de tudo na palavra como materialização da ideologia por meio da linguagem. Para compreender o signo "novo mundo" nos posts publicitários da Latam, partiremos dessa discussão teórica que compreende a palavra como meio fundamental para a materialização da ideologia publicitária.

\section{0 enunciado concreto e sua abordagem metodológica}

Na perspectiva do enunciado concreto, Volóchinov (2019, p. 128) afirma que "nasce, vive e morre no processo da interação social entre os participantes do enunciado". O caráter dessa interação entre os participantes é que dará forma e caráter ao enunciado. Nesse sentido, elaborado no entorno do diálogo social vivo, uma análise do enunciado não pode considerar somente seus elementos linguísticos, ou seja, exclusivamente materiais. Isso é parte importante em sua constituição, em seu jeito de ser linguageiro, isso redundaria em uma análise linguística meramente abstrata. É preciso entender no contexto de um enunciado concreto o caráter das palavras ditas que são sempre impregnadas de subentendido e de não dito.

Bakhtin (2015) argumenta que há um trabalho incessante de forças que estratificam a língua e que assim não permanece uma palavra sequer que não seja acentuada, como língua de dicionário, por assim dizer, "palavra de ninguém". Nesse contexto, a lingua é perpassada pela avaliação dos sujeitos, conforme afirma Bakhtin (2015, p. 69):

Todas as palavras exalam uma profissão, um gênero, uma corrente, um partido, uma determinada obra, uma determinada pessoa, uma geração, uma idade, um dia e uma hora. Cada palavra exala um contexto e os contextos em que leva sua vida socialmente tensa; todas as palavras e formas são povoadas de intenções. 
Em sua vida socialmente tensa, a palavra - no sentido amplificado que se deve dar ao termo slovo em russo 7 - vive pelo embate com outras palavras em que se reveste de avaliação social; nessa arena de encontro de palavras, os sentidos não passam incólumes. As palavras são o campo no qual se dão as lutas de classes que carregam para os enunciados o tom axiológico da esfera de circulação, assim, disseminam os valores com que estiveram em contato/conflito. Mas o estudo de um enunciado concreto no interior das ciências humanas, tal como se concebe na perspectiva bakhtiniana, deve se dar levando em conta mais que apenas sua materialidade significante que é amplificada pelo exterior ao enunciado, isto é, o contexto social e histórico em que os enunciados emergem reflui para seu modo de ser discursivo.

Os posts da Latam são enunciados concretos permeados de sentidos que correspondem a um específico momento social e também histórico: a pandemia de COVID-19 e suas implicações. Isso significa que para compreendê-lo o analista não pode desconsiderar o contexto em que é veiculado (ano de 2020), o público ao qual é destinado (os clientes da Latam) e também o ambiente de sua propagação (o virtual, na rede social Facebook).

Destarte, a compreensão e a avaliação de um enunciado sempre se darão considerando a conjunção de uma parte de materialidade significante (constituida do encontro de palavras, sempre retomadas dos lábios de outros, sempre já valoradas, envoltas em um contexto de percepção particular) e um conjunto complexamente elaborado pela avaliação social. Em outros termos, um enunciado não se apresenta apenas sob a luz de influências exteriores à linguagem, a vida penetra internamente o enunciado por meio da avaliação social na medida em que se forma pelo conjunto de palavras que vivem essa vida tensa no mundo social. Essa categoria de compreensão do enunciado em contexto históri- co-social carrega para as formas da língua (para sua materialidade, efetivamente, não apenas linguistica em alguns casos) as acentuações da comunidade de linguagem em que o falante se localiza ao enunciar.

A entonação, nesse sentido, cumpre papel essencial na medida em que traz aos enunciados o que Volóchinov (2019, p. 129) denomina uma "energia da situação cotidiana para a palavra, atribuindo ao todo linguisticamente estável um movimento histórico vivo e um caráter irrepetível". Nessa medida, as formas da língua que podem se repetir infinitamente nos diversos enunciados em que venham a aparecer são enformadas pelo caráter singular de irrepetibilidade de cada enunciado e se inscrevem dessa maneira na historicidade.

Um enunciado entra na comunicação discursiva como um elo de uma cadeia complexa de interrelações discursivas, responde a um alhures e projeta em sua emergência uma prévia de respostas futuras. Em seu projeto discursivo, os enunciados bebem dessa energia da situação da palavra em sua condição cotidiana, isto é, do caldo comunicativo social, e respondem à realidade. Nessa perspectiva, um enunciado se constitui a partir de um projeto de dizer em que se cruzam a materialidade da linguagem e a avaliação social, entendida como a orientação de um enunciado na atmosfera axiológica (MEDVIÉDEV, 2012). Se concordarmos com Bakhtin (2011a, p. 313) que afirma que "o linguístico é apenas um meio", teremos de partir da análise e descrição do meio - em nosso caso, não apenas verbal, mas verbovisual - para ir mergulhando na profundidade da compreensão desse discurso sobre o "novo mundo" que a Latam Airlines quer vender aos seus clientes.

Dada sua irrepetibilidade, os enunciados concretos se inscrevem na historicidade, assim, sua fisionomia histórica é determinada pela avaliação social. De acordo com Medviédev (2012, p. 185):

7 Conforme Souza e Miotello (2019), as traduções em diversas linguas ocidentais (português, espanhol, francês, inglês e italiano) traçam uma história de interpretação do vocábulo russo "slovo". Conforme a língua e a edição/tradução pode ser traduzido como "discurso" e como "palavra". 
De fato, é impossivel compreender um enunciado concreto sem conhecer sua atmosfera axiológica e sua orientação avaliativa no meio ideológico. Por aceitar um enunciado não significa capturar seu sentido geral como capturamos o sentido de uma "palavra do dicionário". Entender um enunciado significa entendê-lo no contexto da sua contemporaneidade e da nossa (caso elas coincidam). É necessário compreender o sentido no enunciado, o conteúdo do ato e a realidade histórica do ato em sua união concreta e interna.

Na confluência entre o sentido do enunciado, o conteúdo do ato e a realidade histórica, nossa análise se constituirá para entender o signo ideológico "novo mundo" a partir dos enunciados anteriormente explicitados. Nesse sentido, trataremos dos enunciados em que esse signo aparece no horizonte apreciativo de sua emergência a partir de uma análise ancorada em uma materialidade significante que constitui o modo de ser discursivo do enunciado. Assim, nossa análise está organizada por meio de um trabalho com o material linguístico e não linguístico que os enunciados apresentam para desse ponto de vista observar como o sentido do signo "novo mundo" se desenvolve do discurso publicitário da Latam Airlines sobre a pandemia de Coronavírus, durante o ano de 2020.

Dessa perspectiva, a relação entre os elementos linguísticos dos enunciados (aquilo da ordem da materialidade significante) e os elementos exteriores é constitutiva de sua forma e todo o fundo em que se projeta um enunciado está também em seu interior. O estudo dos enunciados, na perspectiva de Bakhtin (2011a), se dá no âmbito de uma ciência humana. Sobre isso, o autor afirma que:

Quando estudamos o homem, procuramos e encontramos signos em toda parte e nos empenhamos em interpretar o seu significado. Estamos interessados primordialmente nas formas concretas dos textos e nas condições concretas da vida dos textos, na sua inter-relação e interação (BAKHTIN, 2011a, p. 319).

Portanto, ao estudar os enunciados no interior das ciências humanas, nossa reflexão se orienta à interpretação dos signos que aparecem materialmente em textos. Desse modo, se interessam com primazia as "formas concretas dos textos" e "as condições concretas da vida dos textos", trabalharemos com os enunciados partindo de uma análise de suas condições materiais. Portanto, partiremos da noção de signo ideológico, para chegar, em seguida, a discussões de ordem discursiva sobre as possiveis compreensões do signo "novo mundo" no contexto pandêmico.

\section{Um "novo mundo" para viajar no discurso publicitário da Latam}

A pandemia ocasionada pelo Coronavírus suscitou diversos tipos de enunciados nas mais diferentes esferas da comunicação humana. $\mathrm{Na}$ esfera publicitária, observamos um movimento imediato das marcas em (re)configurar seu "projeto de dizer", adaptando-o ao momento, atualizando-o, conforme as mudanças de ordem sanitária, por meio da linguagem, especialmente, conforme já vimos, de signos ideológicos (VOLÓCHINOV, 2017) e enunciados concretos (BAKHTIN, 2015; VOLÓCHINOV, 2019). Nesse contexto, além de uma preocupação das marcas em evidenciar seus posicionamentos diante da pandemia, com o objetivo de mostrar aos seus clientes um possivel compromisso social, também precisaram pensar estratégias para não perderem vendas e se manterem no mercado. Por isso, o discurso publicitário atuou e atua de forma incisiva na construção ideológica de um "novo normal".

Dessa maneira, conforme mencionamos, tomamos como corpus deste artigo três posts publicitários da Latam Airlines, que compreendemos como enunciados concretos, sociais e históricos, publicados em sua página no Facebook, entre os meses de maio e setembro de 2020. O primeiro post foi publicado em 21 de maio, o segundo em 30 de julho e o terceiro em primeiro de setembro. Para o recorte foram observados os enunciados constituidos de imagens e texto, excluindo, assim, outros tipos de enunciados, como aqueles apenas verbais e os filmes publicitários. Além disso, consideramos para as análises os enunciados verbovisuais que trouxessem em sua materialidade o signo ideológico "novo mundo" 
que neste caso totalizaram três posts entre os meses coletados.

A partir das primeiras notificações de casos de COVID-19 e dos primeiros decretos proibindo aglomerações no Brasil, a marca publicou posts informativos em sua página no Facebook, sobre cancelamentos, atrasos e remarcações de voos. Como respostas aos posts, diversos clientes deixaram comentários reclamando sobre a demora no atendimento, transtornos ao realizar suas viagens programadas e também dificuldades em receber reembolsos de voos cancelados. Observamos que a pandemia exigiu que a empresa, em sua publicidade, se posicionasse rapidamente a fim de manter tanto sua credibilidade com aqueles que já eram clientes quanto sua imagem externa, com aqueles que ainda não são, preocupando-se em publicizar uma imagem de segurança, higiene e controle da situação em seu projeto de dizer.

Em busca da construção desse projeto de dizer, surgiu o signo ideológico "novo mundo" nos posts publicitários da Latam no Facebook. O primeiro foi publicado em 21 de maio de 2020, com 317 curtidas, 438 comentários e 18 compartilhamentos: ${ }^{8}$

Figura 1 - Post publicitário 1: a emergência do "novo mundo"

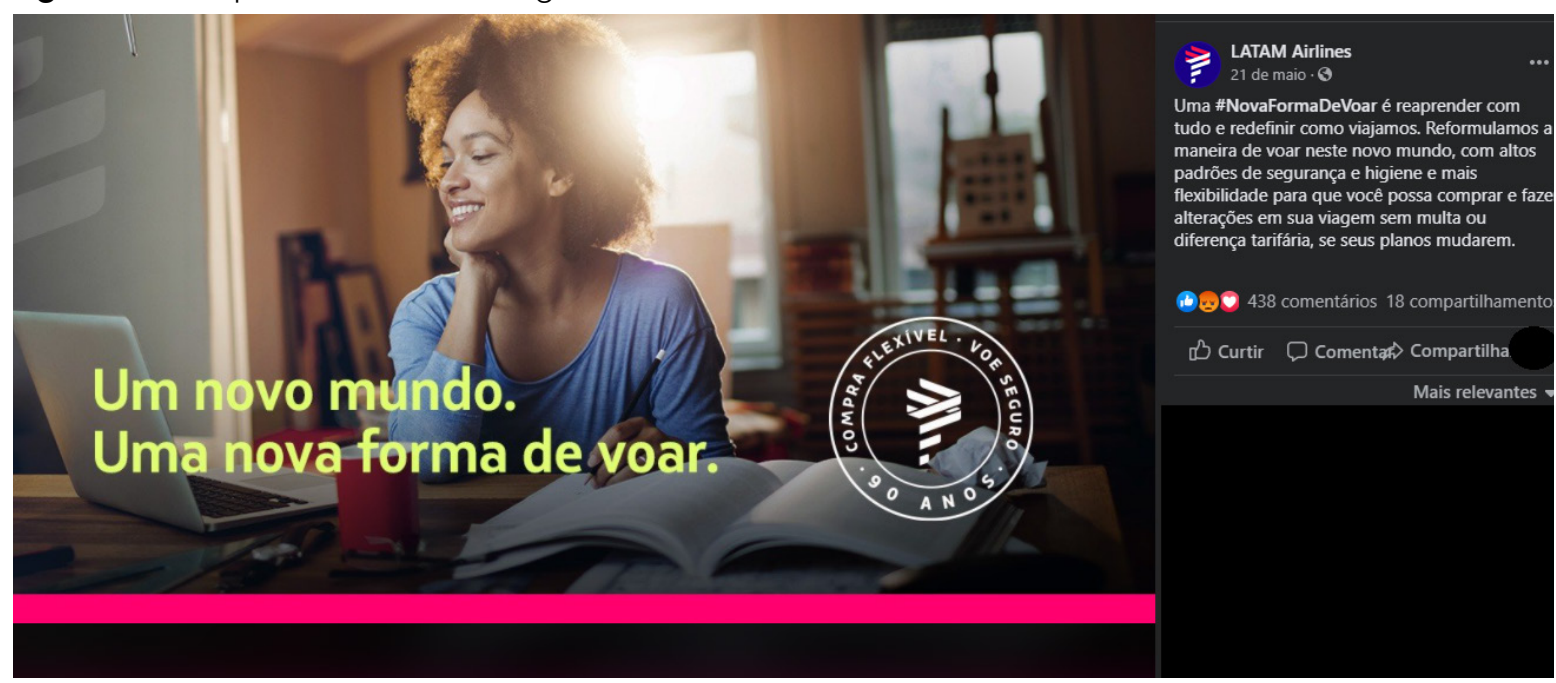

Fonte: Perfil LATAM Airlines no Facebook (2020).

O post é constituido tanto pelo enunciado verbovisual quanto pela sua legenda. A parte visual é composta por uma mulher jovem, negra, que está sentada à mesa, com cadernos e livros próximos, fazendo anotações, sorrindo e olhando para a tela de um notebook; todos esses elementos trazem à tona o contexto das aulas remotas. Em maio de 2020, as aulas oferecidas pelas instituições de ensino no sistema remoto eram ainda muito recentes, uma novidade que poucas pessoas estavam usufruindo, já que exigia que os estudantes dispusessem de aparelhos como computadores ou celulares e acesso de qualidade à internet. Essa realidade, sabemos, não é possivel para todos os brasileiros, uma vez que o país ainda apresenta crescente desigualdade social. ${ }^{9}$

Ao fundo, observamos que o ambiente é claro, a dispor de iluminação solar. Também há alguns objetos como quadros encostados na parede e

8 Data da consulta: 12 dez. 2020

9 Pesquisas realizadas no início da pandemia pelo Instituto de Pesquisa Econômica Aplicada (Ipea) evidenciaram que aproximadamente seis milhões de estudantes não tinham acesso à internet para acompanharem as aulas on-line. Disponivel em https://glo.bo/3s7YRbX Acesso em: 12 dez. 2020. Uma outra pesquisa realizada pelo Instituto Brasileiro de Geografia e Estatística (IBGE) constatou que 30\% dos domicilios no Brasil não têm acesso à internet. Os números são expressivos e revelam a desigualdade que foi ainda mais acentuada no pais (Disponivel em https://bit.ly/35q0oC4. Acesso em: 12 dez. 2020). 
um cavalete de pintura ao lado direito da imagem, desfocado. Outros objetos como a caneca de café e o relógio de pulso posicionados em cima da mesa, retomam o contexto do lar, pois, a caneca traz à tona o sentido de aconchego e o relógio fora do pulso indica a não necessidade de usá-lo, já que não há compromissos para se cumprir fora de casa. Em outras palavras, um ambiente muito convidativo e aconchegante para se manter em casa, durante a quarentena.

O enunciado verbal "Um novo mundo. Uma nova forma de voar" materializa o signo ideológico "novo mundo", que aliado ao contexto do ensino remoto reforça o sentido sobre o que é considerado "novo". O mundo que agora desperta aos olhos tanto da empresa quanto dos clientes exige que esses olhos estejam dispostos a se tornarem resilientes e adaptarem-se a outra realidade, em que o contato físico é evitado.

O enunciado "Um novo mundo." constata a emergência do momento histórico atípico anunciado em 2020 pela pandemia global. Ademais, é importante destacar que o post em análise foi o primeiro em que a marca apresentou o signo ideológico "novo mundo", em seu Facebook, ainda nos primeiros meses do isolamento social (maio de 2020).

"Uma nova forma de voar" é apenas uma das inúmeras possibilidades que o "novo mundo" viabiliza, pois, se é possivel continuar os estudos ou até mesmo o trabalho, também é possivel voar (de preferência pela Latam). É, justamente, sob essa premissa que é construido seu projeto de dizer, constatando que há a emergência de um "novo mundo" e logo, uma nova forma de voar, mesmo que essa forma ainda não esteja definida ou clara para a Latam ou para seus clientes, já que em maio de 2020, ainda não havia uma compreensão socialmente compartilhada do sentido que o isolamento estava impondo, pois tudo ainda era muito recente.

Veremos que o signo "novo mundo" vai se transformando ao sabor dessa compreensão cada vez mais clara, tanto no sentido social quanto no sentido do discurso publicitário da Latam. Observemos agora, a legenda do post, que também contribui para a construção dos sentidos, especialmente, do signo ideológico "novo mundo":

[Legenda do post publicitário 1]: Uma \#NovaFormaDeVoar é reaprender com tudo e redefinir como viajamos. Reformulamos a maneira de voar neste novo mundo, com altos padrões de segurança e higiene e mais flexibilidade para que você possa comprar e fazer alterações em sua viagem sem multa ou diferença tarifária, se seus planos mudarem (LATAM AIRLINES, 2020).

Os verbos aprender, definir e formular aparecem com o prefixo "re-", que indica uma nova tentativa, de "aprender com tudo", de "definir como viajar" e de "formular a maneira de voar". O uso do prefixo materializa a necessidade da marca de reconfigurar seu discurso publicitário para um contexto que não é favorável às aglomerações, comuns nos aeroportos, e às viagens, principal atividade econômica da Latam. Logo, o deslocamento de seu discurso é preciso para tornar favorável e otimista sua imagem diante dos clientes, para não perder vendas, o que redundaria em consequências financeiras. $O$ uso desses verbos com prefixo "re-" corrobora à invenção desse "novo mundo" em que a Latam pretende vender passagens aéreas com tarifas flexiveis e "com altos padrões de segurança e higiene". Portanto, desde já, esse "novo mundo" nasce exigindo cuidados e a Latam explica, neste primeiro post, que a revisão de sua "forma antiga de voar" (já que emerge uma nova), produziu mudanças efetivas em sua política de vendas permitindo fazer alterações sem onerar o cliente.

O segundo post publicitário foi publicado em 30 de julho de 2020 e conta com 232 curtidas, 188 comentários e 14 compartilhamentos. ${ }^{10}$ Neste caso, o signo ideológico "novo mundo" também constitui o enunciado verbovisual em análise, no interior da pergunta que a Latam faz aos seus clientes, conforme a Figura 2: "Neste novo mundo, qual seu próximo voo?".

10 Data da consulta: 12 dez. 2020. 
Figura 2 - Post publicitário 2: o "novo mundo" em consolidação

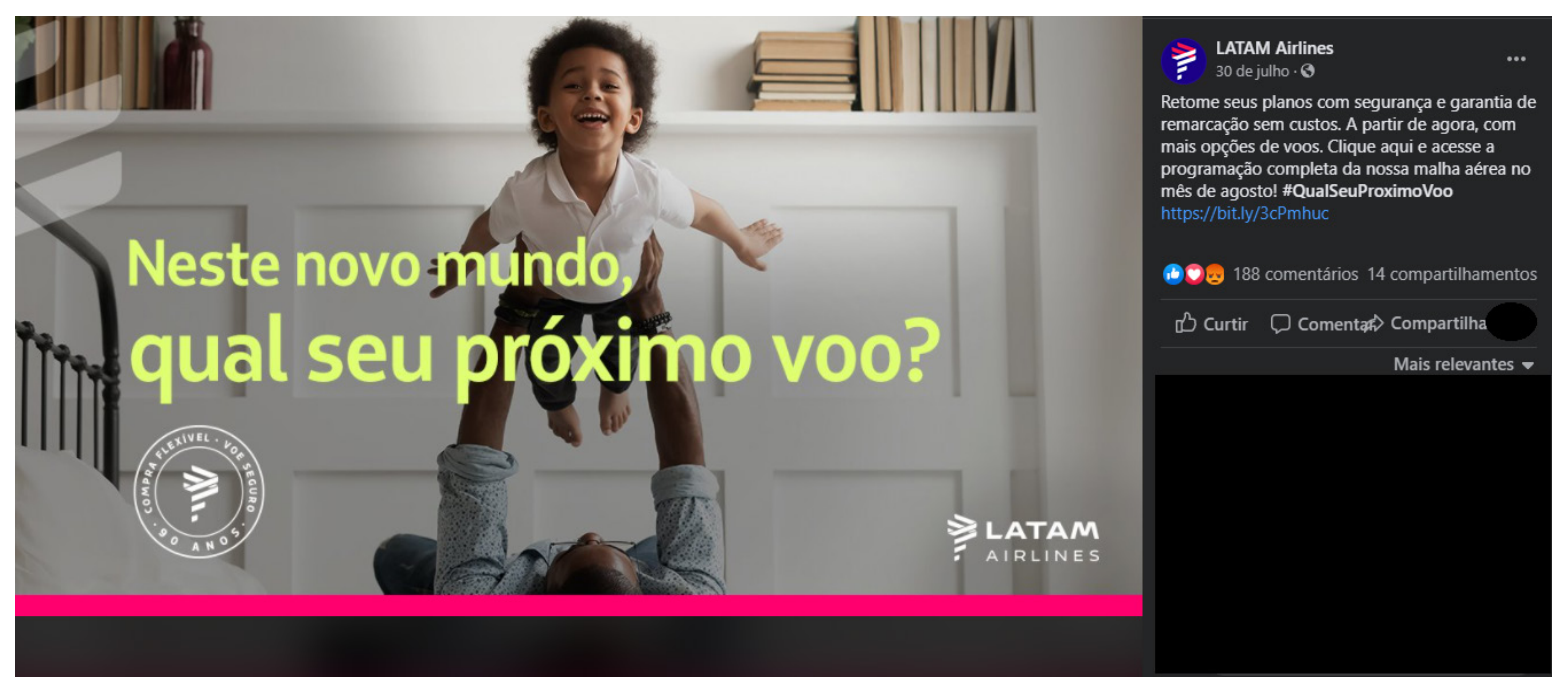

Fonte: Perfil LATAM Airlines no Facebook (2020).

Novamente, no post representado na Figura 2, o ambiente familiar e o conforto do lar são retomados, as paredes brancas com livros em uma prateleira alta na parede, a cabeceira da cama e os travesseiros, que remetem ao quarto, servem de suporte para dois membros dessa possivel familia, pai e filho, ambos são negros. O pai levanta o menino que sorri com olhar fixo para frente e com os braços abertos, em formato de "aviãozinho". A criança está bem-vestida, com os pés descalços, o pai deitado na cama, não aparece seu rosto, mas percebe-se que também está bem-vestido e concentrado em sua brincadeira com o filho.

É interessante observar a disposição dos elementos no enunciado, em que pai e filho são centrais na imagem, o corpo da criança em formato de avião recupera sentidos sobre viagens, momentos em familia, diversão. O movimento de abrir os braços fazendo "aviãozinho" alude tanto ao meio de transporte quanto à brincadeira comum entre pais e filhos. Mas, ao mesmo tempo, também se refere, considerando a arquitetônica do enunciado, ao sentido sobre a possibilidade de realizar viagens de avião, mesmo que em um contexto pandêmico. Destarte, novamente, são enfatizados os valores positivos de um novo mundo que a Latam quer construir discursivamente para vender passagens áreas. No novo mundo à moda Latam, é possível viajar com tranquilidade e em familia, uma vez que a ideia de novo mundo é mais assimilável em julho de 2020.

No primeiro post "Um novo mundo" aparecia como a emergência da construção discursiva na publicidade da empresa aérea, constatando a ideia de um "novo mundo" que obriga a afirmar a existência de uma maneira também nova de voar. No segundo post, em julho, esse signo aparece em consolidação, pois, o "novo mundo" é anunciado pela forma contraida de preposição "em" e o pronome demonstrativo "este", para remeter à enunciação e suas características dêiticas. ${ }^{11}$ Dada a proximidade com esse "novo mundo" constatada pelo post, o discurso publicitário da Latam

\footnotetext{
11 A dêixis, entendida conforme Benveniste (2005), refere ao aqui e o agora do momento de enunciar. No movimento entre o sistema da língua - mera possibilidade virtual - e a enunciação - cada vez única, constituida pela apropriação do sistema -aparece como um momento em que um locutor transforma língua em fala. Na teoria benvenisteana, há uma diferença entre enunciação e enunciado e, a primeira é a apropriação de um aparelho formal em que se transforma a língua em fala, o segundo termo é o resultado da enunciação em outras palavras, a enunciação é o dizer, o enunciado é o dito. Na teoria bakhtiniana, o termo russo viskázivanie pode ser traduzido como "enunciado" (VOLÓCHINOV, 2017, 2019) ou "enunciado e/ou enunciação" (VOLOCHINOV, 2013) a depender do contexto.
} 
se vale das mudanças na compreensão social do tema relacionado à pandemia. Se em maio tudo ainda era muito recente, em julho o cenário era outro e a empresa precisava retomar suas atividades com total força. Assim, o enunciado verbal interpela o leitor como possivel cliente ao perguntar "qual seu próximo voo?".

Dessa maneira, a possibilidade de voar em segurança e de remarcar as passagens sem custos retorna como uma possibilidade para auxiliar à retomada de planos de viagens. Nessa perspectiva, pai e filho aparecem brincando de aviãozinho como uma metáfora para essa possivel viagem para conhecer esse "mundo novo". Uma vez mais, o "novo mundo" faz circular valores positivos e, em julho, quando os números de contágio e de mortes por COVID-19 no Brasil ainda estavam em ascendência, o "novo mundo" da Latam é um mundo em que voar é preciso e retomar viagens é uma forma de viver. Acresce às discussões levantadas, a legenda do post, que também traz informações importantes, como o discurso sobre segurança e sobre retomada de planos, já prenunciado na primeira legenda do post 1 (Figura 1).

[Legenda do post publicitário 2]: Retome seus planos com segurança e garantia de remarcação sem custos. A partir de agora, com mais opções de voos. Clique aqui e acesse a programação completa da nossa malha aérea no mês de agosto! \#QualSeuProximoVoo https:// bit.ly/3cPmhuc (LATAM AIRLINES, 2020).

Essa legenda é introduzida pelo verbo "retomar" em que figura novamente o prefixo "re-" corroborando com a ideia de um novo cenário contra o qual se erige o "mundo novo". Se cotejarmos a legenda do primeiro post e essa do segundo, a ênfase na primeira é mais informativa, enquanto nessa segunda temos um foco mais comercial. Essa questão também é uma diferença se comparamos os posts como um todo: no caso do primeiro, a perspectiva informativa é predominante; no caso do segundo, a própria parte verbal do enunciado do post convoca a comprar/ planejar viagens futuras. Sobre a intervenção da avaliação social no modo de ser discursivo dos enunciados, a reflexão de Medviédev (2012) sobre a palavra e avaliação social é importante. Para o autor,

[...] cada elemento da língua tomado como material obedece às exigências da avaliação social. Apenas aquele elemento da língua que é capaz de satisfazer suas exigências pode entrar no enunciado. A palavra torna-se um material do enunciado apenas como expressão da avaliação social. Por isso, a palavra entra no enunciado não a partir do dicionário, mas a partir da vida, passando de um enunciado a outros. A palavra passa de uma totalidade para outra sem esquecer o seu caminho (MEDVIÉDEV, 2012, p. 185).

Conforme essa perspectiva de uma memória da palavra, que carrega em si o caminho que percorreu em sua vida discursiva, os elementos da avaliação social atuam de uma forma anterior à produção do discurso, moldando externamente a forma de ser dos enunciados. Somente os elementos da lingua que obedecem às exigências da avaliação social penetram nos enunciados, sempre conduzindo para o texto os valores socialmente compartilhados. Essas expressões com perspectiva de novidade as quais nos referimos ("novo normal", "novo coronavirus", "novo mundo") desde o começo desta reflexão se instauram nos enunciados porque a situação nova experimentada mundialmente faz aparecer signos que descrevam esse acontecimento novo na vida humana.

Assim, o adjetivo "novo" sempre se contrapõe a "velho", "anterior" ou "antigo", mas nem sempre precisa explicar essa contraposição, como é o caso em análise, porque estamos habituados pela experiência social que compartilhamos a entender o sentido do "velho normal" ou apenas "normal" em que o adjetivo aparece em elipse, ou é desnecessário. O uso desse adjetivo, então, nessa porção de signos que desenham a novidade mundial trazida pela pandemia remete a essa história de sentidos em que o "velho" já é dado, não é preciso descrever/explicar a seu respeito. O desenvolvimento de outras formas de voar, mas também de estar em sociedade (ensino remoto emergencial, home office etc.), são trazidas para a vida da linguagem porque são urgentes formas de narrar os acontecimentos impostos pela 
quarentena e pelo isolamento social. Assim, com a semântica da novidade que a avaliação social impõe para explicar as experiências diferentes que a humanidade passou a utilizar para viver em sociedade, o "novo" e suas variantes aparecem no discurso social como formas de expressar a avaliação social do contexto pandêmico em curso, são o modo como a sociedade interpretou o mundo, seu investimento simbólico de compreensão.

Destarte, a existência de um "novo mundo" sendo introduzida no discurso da Latam no post 1 (Figura 1) é revisada no post 2 (Figura 2) quando, inclusive, pela compreensão social sobre o assunto da pandemia, a Latam se coloca em uma posição de vender passagens, uma vez que em julho essa ideia de retomada era cada vez mais forte nos discursos da mídia, a respeito da economia, sobretudo, por meio do signo "novo normal". Ao mesmo tempo em que há um movimento da sociedade para retomar suas atividades, de acordo com as regras impostas pelo "novo normal", sob a justificativa de alavancar a economia, há também um trabalho ideológico da Latam para construir um "novo mundo" a ser descoberto, de modo que a pergunta "Neste novo mundo, qual seu próximo voo?" do post publicitário convida a viajar.

A questão que a legenda do post 2 (Figura 2) traz é que, a partir do início de agosto de 2020 , a malha aérea da Latam estava maior em função dessa retomada de viagens em andamento. Na Figura 2, especialmente, em sua legenda, a possibilidade do hiperlink que redireciona à página de consulta da Latam com a nova malha aérea, a questão da segurança e da remarcação sem custos são os atrativos para se formular em pergunta a ideia que já estava em emergência do "novo mundo", ainda na primeira postagem. No post 2, em contraponto, o "novo mundo" já existe e é compreensivel, dessa maneira, conhecendo o que implica esse "novo mundo", isto é, os necessários cuidados, já podem ser retomados os planos de forma segura. Além disso, o discurso sobre segurança surge durante a pandemia como um novo critério tanto para a empresa realizar suas publicidades, quanto para os consumidores realizarem suas compras.

Nesse sentido, não basta que a marca se mostre preocupada com a situação sanitária do país, é necessário, também, oferecer opções para que seus consumidores possam viajar com segurança, por isso, o discurso da segurança e da higiene aparecem de forma expressiva desde a primeira postagem em análise. O contexto é que foi se transformando conforme a compreensão social do tema da pandemia. É importante destacar que o dêitico "agora" indica o momento da publicação do enunciado, julho de 2020, período em que o comércio e as demais atividades retornavam gradualmente às suas atividades no Brasil, por meio de flexibilizações de decretos. ${ }^{12}$ Assim, oferecer mais opções de voos para seus clientes e flexibilidade na compra e na remarcação passou de luxo das tarifas de viagem mais altas para uma forma de lidar com a instabilidade, desse modo, é um sinal que a empresa apresenta sobre como funcionará no "novo normal" que faz emergir o "novo mundo" como um signo. Ademais, vale ressaltar que o discurso de segurança e higiene, em sua publicidade, não significa, somente, a garantia de aeronaves revisadas, em bom estado, com pilotos e tripulações treinados e qualificados, mas que a viagem pela Latam não irá prejudicar a saúde dos passageiros em função do contágio de coronavirus.

Se levarmos em conta nesses dois primeiros posts que tratam da emergência e do "novo mundo" em consolidação, o vocabulário que remete ao virus inexiste. Palavras como "pandemia", "isolamento social" ou mesmo "coronavírus" não aparecem, por isso, entendemos que os valores que o "novo mundo" mobilizam como signo recortam as possibilidades que a publicidade movimenta. O "novo mundo" como um signo aparece sem se fazer explicar o mundo antigo a que se contrapõe, sem precisar haver uma discussão sobre como eram os voos da Latam antes. Assim, o "novo" aparece mobilizando somente aspectos positivos - no primeiro post, o

12 Observamos que o link que está na legenda do post ainda funciona, de acordo com a malha aérea atual, assim, agora como um dêitico dessa enunciação pode remeter ao mês corrente (janeiro de 2021) também. 
"novo mundo" ensina "uma nova forma de voar", sugere "reaprender" e a "redefinir" a maneira de viajar. A Latam apresenta, em concomitância, à invenção de um "novo mundo" uma "nova maneira de voar", que apresenta todos os aspectos positivos relacionados ao aprendizado e às mudanças.

Acerca disso, a mudança sempre é concebida como positiva, veja-se o sorriso no rosto da mulher que aparece no primeiro post (Figura 1), veja-se a forma como o menino aparece também sorrindo no segundo. A experiência de um "novo mundo" a conhecer nessas publicidades de viagem está ligada, exclusivamente, a valores eufóricos, assim, a doença e a pandemia são obliteradas quase totalmente; não fosse a menção ao discurso da segurança e da higiene, o "novo mundo" apagaria qualquer perspectiva de um agente infecioso gravíssimo como o SARS-CoV-2, que em julho já havia vitimado quase cem mil brasileiros. ${ }^{13}$ Se tratássemos apenas desses dois posts, a política nova que a publicidade em torno do signo "novo mundo" introduz pareceria mesmo signica, uma vez que deixa de tratar de um tema de amplo debate nacional que ditou as pautas midiáticas e políticas no mundo todo.

Os estudos de Henry Jenkins sobre relações entre marca e consumidor trazem contribuições para compreender a questão do marketing. Para Jenkins (2009), os profissionais de marketing buscam constantemente não apenas fazer com que os consumidores realizem compras, mas que também estabeleçam uma relação de longo prazo com a marca. Por isso, observamos, por meio das escolhas linguísticas da marca que ao utilizar verbos com prefixos "re-" (redefinir, reaprender, reformular) e mesmo substantivo (remarcação) busca sedimentar essa relação de contato, de compra, de proximidade, que foi abalada pela obrigatoriedade do isolamento social dado pela pandemia.

Destarte, o signo "novo mundo" no post publicitário 2 (Figura 2) não atua de forma isolada: seus sentidos são compreendidos porque a eles são estabelecidos elos anteriores e futuros. No post 2 o "novo mundo" aparece já valorado pela comunidade social que se encontra na página do Facebook da Latam, no final do mês de julho de 2020. Assim, a experiência social compartilhada a respeito da pandemia e a retomada gradativa de boa parte das atividades econômicas, que foram prejudicadas em função da quarentena obrigatória dos primeiros meses, apresenta uma construção verbal que figura "neste novo mundo", no qual o signo em análise aparece acoplado à forma contraída da preposição "em" e do pronome demonstrativo "este". A questão é que o signo "novo mundo" no post 2 aparece materialmente valorado por uma experiência acumulada, isto é, no contexto da avaliação social em que o velho mundo está distante, "agora" - para retomar o dêitico que aparece na legenda - é o momento de retomar os planos de viajar apesar de tudo.

Conforme explica Volóchinov (2017), a compreensão de um signo ideológico se atrela aos elos que estabelece entre esse signo e outros. Em suas palavras,

[...] a compreensão de um signo ocorre na relação deste com outros signos já conhecidos; em outras palavras, a compreensão responde ao signo e o faz também com signos. Essa cadeia da criação e da compreensão ideológica, que vai de um signo a outro e depois para um novo signo, e portanto material, a outro elo também signico. Essa cadeia nunca se rompe nem assume uma existência interna imaterial e não encarnada no signo (VOLÓCHINOV, 2017, p. 95).

Como uma cadeia compreensiva estabelecida com o signo, entre a emergência do "novo mundo" na primeira postagem e sua consolidação na segunda, os sentidos atribuidos ao signo se desenvolvem acompanhando a experiência compartilhada socialmente sobre o tema da pandemia. As viagens já podem ser retomadas e o discurso de prevenção e segurança durante os voos dá forro para o posicionamento da Latam no enfrentamento da temática. Dito de outro modo, nem mesmo uma pandemia mundial pode frear os planos de viagem de uma família feliz como a que se apresenta no post 2 (Figura 2). É dessa

\footnotetext{
13 Segundo o site Bol, ao final de julho o Ministério da Saúde registrava mais de 93 mil mortes. O mês de julho também foi considerado pelo site, em 01-08-2020, como o mês mais mortal da pandemia, até aquele momento. Disponivel em: https://bit.ly/3nwQraq. Acesso em: 9 jan. 2021
} 
perspectiva que a parte verbal perguntando sobre qual o próximo voo é tão significativa para a construção de um "novo mundo" a conhecer/ ser explorado.

Passemos, agora, ao post publicitário 3 (Figura 3), que foi publicado em primeiro de setembro de
2020, conta com 234 curtidas, 83 comentários e 9 compartilhamentos ${ }^{14}$. O signo ideológico "novo mundo" também constitui o enunciado verbovisual em análise, no interior do enunciado verbal: "Nesse novo mundo, nosso próximo voo é facilitar a vida de quem salva tantas outras".

Figura 3 - Post publicitário 3: o "novo mundo" consolidado

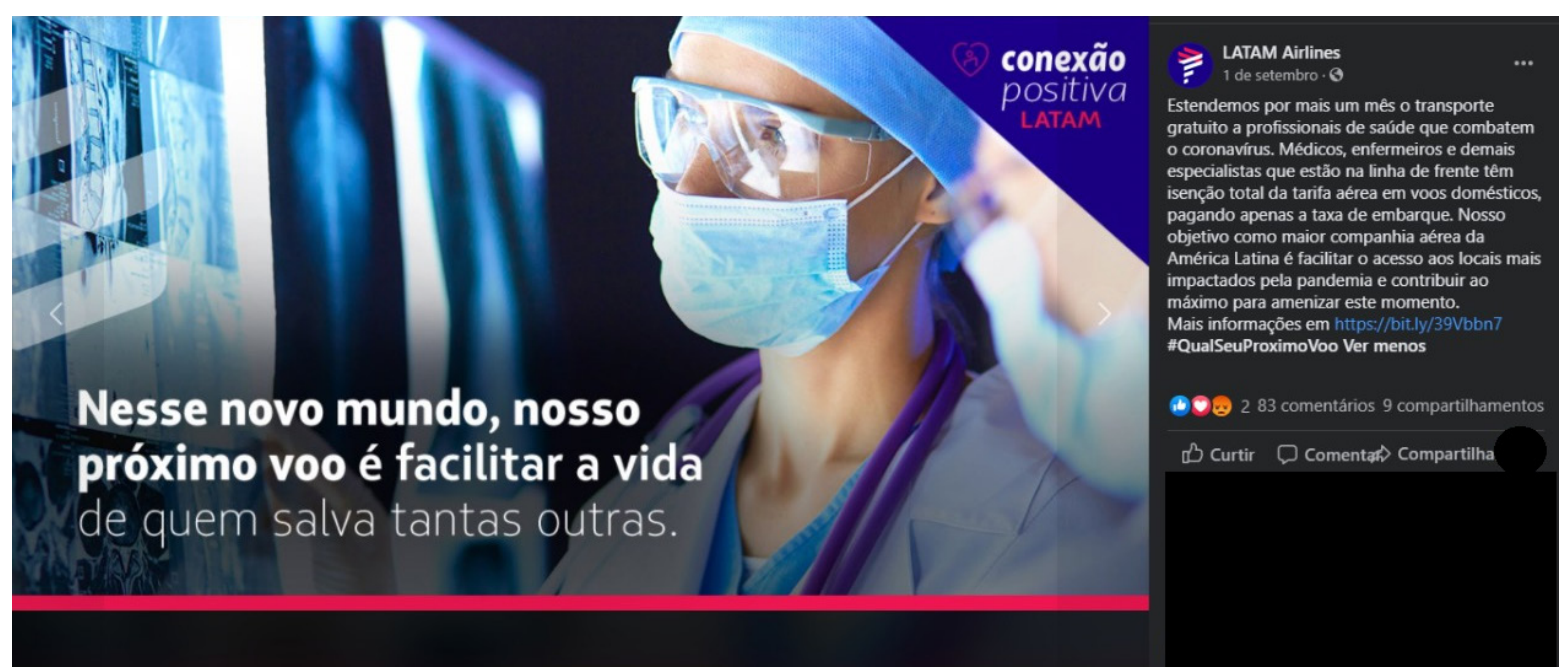

Fonte: Perfil LATAM Airlines no Facebook (2020).

O post 3 (Figura 3) gera uma terceira possibilidade de compreensão do signo "novo mundo", já que agora a temporalidade da pandemia e a compreensão social a seu respeito são novamente diferentes. No mês de setembro, observamos, pelas construções linguísticas da postagem, que o "mundo novo" é já dado, algo muito comum, totalmente diferente da compreensão que se instaurava no post 1, por exemplo. Se no post 2 discutimos que o uso da forma contraída de preposição e pronome demonstrativo "neste" implicava um "mundo novo" próximo, em que o locutor estava inserido, e ainda recente, aqui a forma "nesse" de características linguísticas próximas (contração de preposição "em" e pronome demonstrativo "esse") implica uma certa distância entre locutor e propriamente o "novo mundo". Essa distância do locutor em relação à enunciação flagrada pelo uso dessa expressão que produz anáfora propõe o "novo mundo" como já consolidado.

Nessa esteira, analisando ainda as escolhas linguísticas presentes no post 3, o pronome pos- sessivo "nosso" é utilizado de modo a marcar a proximidade entre marca e consumidor, já que o enunciado "nosso próximo voo é" responde diretamente a outro enunciado que norteia a campanha que, inclusive, é uma pergunta: "Neste novo mundo, qual seu próximo voo?", que aparece no post 2. Dessa maneira, o discurso publicitário da marca evidencia a construção ideológica na qual "próximo voo" não se restringe, apenas, ao ato de voar, de comprar passagens, mas tam

bém de gerar boas ações, suscitando, assim, as emoções de seus interlocutores.

O enunciado do post 3 permite uma paráfrase que serve como chave de leitura para a campanha como um todo: "próximo voo" pode ser substituido sem prejuizos ao tom emocional que se deseja imprimir por "próxima meta" ou "próximo objetivo". Naturalmente, como a empresa em questão é uma empresa aérea, outros substantivos que poderiam ocupar a posição nuclear desse sintagma nominal são substituidos por "voo" ou outros substantivos que remetessem à semântica da

14 Data da coleta: 12 dez. 2020 
esfera de atividade em que se inscreve. Tomando por base essa perspectiva de um "novo mundo" que exige respostas, que pergunta sobre quais são as ações que o interlocutor tomará, a Latam resolve apresentar um investimento emocional ainda mais forte, tentando responder à própria pergunta sobre "Qual seu próximo voo?".

No ramo do marketing, segundo Jenkins (2009), as marcas adotam estratégias que aguçam as emoções dos consumidores com o objetivo de estabelecer uma relação de proximidade. Acerca disso, em um momento de comoção mundial, diante do cenário pandêmico, em que há um acentuado número de mortes e de infectados e frente à exaustão dos profissionais de saúde, a Latam responde à pergunta que propõe ("Qual seu próximo voo?") de forma a apelar ao emocional de seus interlocutores, afirmando que "nosso próximo voo é facilitar a vida de quem salva tantas outras". Para isso, constrói seu enunciado visual relacionado ao ambiente de um hospital a despeito do ambiente doméstico que aparecia nos outros dois posts em análise.

O enunciado visual apresenta uma profissional da saúde, equipada com máscara, óculos de proteção, touca e jaleco, além de equipamentos como um estetoscópio em torno do pescoço. Observa-se também a presença de outro profissional, em desfoque ao lado direito do enunciado; ambos estão atentos analisando um raio-x. Acima, do lado direito, há o nome do projeto da empresa "conexão positiva Latam", que tem direcionado ações que visam auxiliar no combate à pandemia. ${ }^{15}$

A palavra "conexão", em "conexão positiva Latam", funciona como outro exemplo da busca por palavras pertencentes à semântica da esfera de atividade da Latam, inclusive para organizar o discurso de intervenção que ajuda a construir uma imagem social da empresa frente à pandemia. Refere-se tanto à conexão entre voos, comuns em viagens aéreas, quanto à conexão entre pessoas, empresas, ideias, sejam conexões fisicas ou emocionais, por exemplo. Desse modo, a conexão positiva da Latam é contrária ao virus, que no post aparece na medida em que é apresentada a possibilidade de intervenção da empresa. A própria ideia de uma conexão positiva.

Acerca da palavra, Volóchinov (2017, p. 205) esclarece que:

\begin{abstract}
Toda palavra serve de expressão ao "um" em relação ao "outro". Na palavra, eu dou forma a mim mesmo do ponto de vista do outro e, por fim, da perspectiva da minha coletividade. A palavra é uma ponte que liga o eu ao outro. Ela apoia uma das extremidades em mim e a outra no interlocutor. A palavra é o território comum entre o falante e o interlocutor.
\end{abstract}

As relações que são estabelecidas entre o "eu" e o "outro" se dão por meio do uso da palavra, seja quando eu a tomo para constituir a mim mesmo - constituição essa que se dá através do olhar do outro - seja quando o outro a direciona para mim. Funciona, assim, como um território, um lugar, uma ponte que propicia a interação entre falante e interlocutor. Essa interação pode acontecer através de diferentes gêneros discursivos, enunciados e signos ideológicos, suscitando respostas e sentidos, conforme exploramos na seção teórica deste artigo.

As palavras que constituem o enunciado verbal como "vida" e "salva" atuam como pontes (VOLÓCHINOV, 2017), entre o discurso publicitário da Latam e seus interlocutores. A empresa, estrategicamente, escolhe palavras que trazem à tona sentidos positivos - afastando o negativismo próprio do contexto pandêmico - e emotivos destacando os esforços laboriosos daqueles que trabalham para salvar vidas. Isso significa que são os profissionais de saúde que a marca busca "facilitar a vida", já que são eles quem salvam tantas outras. Por meio de sua publicidade são exploradas as emoções de seus interlocutores, comovendo-os, através do reconhecimento prestado a esses profissionais, mostrando-se aliada e em contato com esse grupo.

A legenda do post também evidencia esse posicionamento: 
[Legenda do Post publicitário 3] Estendemos por mais um mês o transporte gratuito a profissionais de saúde que combatem o coronavírus. Médicos, enfermeiros e demais especialistas que estão na linha de frente têm isenção total da tarifa aérea em voos domésticos, pagando apenas a taxa de embarque. Nosso objetivo como maior companhia aérea da América Latina é facilitar o acesso aos locais mais impactados pela pandemia e contribuir ao máximo para amenizar este momento. Mais informações em https://bit.ly/39Vbbn7 \#QualSeuProximoVoo (LATAM AIRLINES, 2020).

O estilo linguístico da legenda com verbos em primeira pessoa do plural como no verbo "estendemos" e, novamente, com o pronome possessivo "nosso" materializam a busca do discurso publicitário da Latam em se aproximar de seus clientes, sejam eles profissionais de saúde ou não. Ao posicionar-se em apoio àqueles que "salvam vidas", a Latam também marca ideologicamente o seu lugar tanto no presente, em busca de manter seus clientes, quanto em relação à sua imagem e como será lembrada após o momento histórico da pandemia do coronavírus. ${ }^{16}$

O objetivo em "facilitar o acesso aos locais mais impactados pela pandemia", logo, "facilitar a vida de quem salva tantas outras" é justificado pela afirmação sobre ser a "maior companhia aérea da América Latina". Nesse sentido, em seu projeto de dizer há uma busca por evidenciar seu posicionamento, de não apenas estar interessada em vender passagens aéreas, mas também de auxiliar no que é de sua natureza: o transporte de pessoas por meio de uma malha área. Assim, se de acordo com Volóchinov (2013) todos os enunciados, cedo ou tarde, são respondidos, a resposta que a Latam almeja ser direcionada aos seus interlocutores é de que não apenas está ajudando no combate à pandemia, como transportando os profissionais que atuam na linha de frente de combate ao vírus. Ademais, como já haviamos destacado no que se refere aos posts 1 e 2 (Figuras 1 e 2), em que há uma ênfase temática mais informativa e mais comer- cial, respectivamente, aqui a perspectiva é mais de intervenção, de mostrar como a empresa está se posicionando "nesse novo mundo".

Nessa perspectiva, ao cotejarmos a análise que realizamos dos primeiros dois posts em que há a presença mais expressiva de questões mais comerciais e informativas, observamos que, nesse último post (Figura 3), a proposta de intervenção é central e quebra com a lógica de afastar o vocabulário de efeitos negativos (aquele que se relaciona ao vírus). Assim, os sentidos relacionados à pandemia de coronavirus aparecem a fortiori na legenda, mas no enunciado verbal do post 3 aparece como metáfora - isto é, não se diz que transportam médicos, enfermeiros e especialistas, mas que facilitam "a vida de quem salva tantas outras" e na imagem aparece uma médica em serviço.

Nessa esteira, a experiência compartilhada a respeito da pandemia traz para o discurso do "novo mundo", que em setembro é entendido como um mundo já conhecido em que as pessoas estão aprendendo a viver, a Latam contribui de maneira propositiva ao transportar pessoas que ajudarão no combate ao vírus. Apesar, então, da semântica do vírus aparecer, sua emergência se dá em uma postagem que trata do compromisso da empresa em combater, ou seja, de forma que traz positividade à marca.

\section{Considerações finais}

Neste artigo, tomamos como corpus três posts publicitários da Latam Airlines publicados em sua página no Facebook, entre os meses de maio e setembro de 2020. Os posts foram publicados durante momentos diferentes de compreensão da pandemia no Brasil e o nosso objetivo foi estudar como os sentidos do signo ideológico "novo mundo" foram constituídos. Nosso recorte privilegiou aqueles posts publicitários que materializavam o signo "novo mundo" e estavam constituidos por imagem e texto.

\footnotetext{
16 É importante ressaltar que não apenas a Latam realizou/realiza ações com o objetivo de auxiliar no combate à pandemia. Outras empresas aéreas, como a Azul Linhas Aéreas Brasileiras, também têm divulgado ações em suas redes sociais, como o post publicado em seu perfil no Instagram, em dezembro 2020, informando que irá transportar, de graça, a vacina contra o coronavirus para todas as cidades nas quais opera. Essa postagem conta com mais de 85 mil curtidas. Assim, quando outras marcas, principalmente, as concorrentes, posicionam-se, é necessária uma resposta aos interlocutores, já que todos os enunciados estabelecem elos com outros (BAKHTIN, 2011b), mostrando também um posicionamento positivo.
} 
Com base nessa amostra discursiva apresentamos uma análise que parte da noção de signo ideológico, de Volóchinov (2017), para construir um percurso interpretativo dos dados em que discutimos três momentos de compreensão da pandemia acoplados ao projeto de dizer da Latam Airlines, quais sejam, um novo mundo em emergência; um novo mundo em consolidação; um novo mundo como já dado. No movimento de compreensão dos sentidos, descrevemos as materialidades dos posts publicitários entendidos como enunciados em que existe uma sobreposição de materialidade verbal e visual. Em seguida, trabalhamos com as relações dialógicas que podem ser estabelecidas a partir dessa descrição, avançando nas camadas do sentido desses signos e cotejando-os para compreender sua maneira de ser discursiva no contexto do discurso publicitário da empresa.

Ao analisarmos o post publicitário 1 (Figura 1), verificamos que a ideia de um novo mundo estava relacionada às caracteristicas urgentes da pandemia, sobretudo no que se refere à quarentena obrigatória e ao isolamento social que passava a fazer parte da vida humana. Assim, esse "novo mundo" que aparece no primeiro post é analisado no contexto do mês de maio, ainda no princípio da ideia de pandemia, em que não havia uma compreensão social consolidada sobre o que era coronavirus, quais seus efeitos e mesmo as possiveis sequelas pela exposição à doença por ele causada. O novo mundo do primeiro post exige cuidados e ensina uma nova forma de voar, isto é, no discurso da Latam esse novo mundo faz aprender a viajar de uma maneira nova.

O segundo post (Figura 2), se comparado a esse primeiro, já se inscreve em um outro momento na experiência da pandemia socialmente compartilhada: o novo mundo que a Latam quer vender é o da retomada das atividades, que começava de maneira gradual, apesar dos números de contágios e mortes por COVID-19 serem cada vez mais ascendente no mês de julho. A despeito dos números da doença no Brasil, as atividades econômicas estavam em franca retomada e os voos da empresa começaram a retornar ao fluxo anterior. Desse modo, a pergunta "Qual seu próximo voo?" faz perceber que a Latam convida o interlocutor a retomar viagens e planos que estavam "engavetados" em função da pandemia.

No terceiro post (Figura 3), a questão se desenvolveu diversamente, uma vez que a pergunta que aparece no post 2 é respondida no terceiro. Dessa perspectiva, compreendemos o post 3 como uma questão mais propositiva, como uma maneira com a qual a pandemia é enfrentada pela marca. Daí uma questão fundamental que aparece no terceiro post e que ajuda a compreender o movimento como um todo: as possiveis paráfrases que 0 terceiro post permite ajudam a elucidar que há toda uma semântica da novidade que se instaura junto à experiência nova que o vírus faz circular.

Os sentidos do signo "novo mundo" vão se desenvolvendo no discurso da Latam acompanhando uma compreensão social da pandemia de coronavirus que ainda enfrentamos. Os sentidos que estudamos do signo "novo mundo" são flagrados em três momentos que descrevem também uma compreensão social da temática da pandemia: quando tudo ainda era recente, o "novo mundo" emerge como uma forma nova de voar, que se é ensinada pelo virus. O "novo mundo" se consolidando aparece em um momento no qual as pessoas estavam aos poucos retomando suas atividades, apesar da cruel pedagogia do vírus, apesar dos números crescentes de contágios e mortes por COVID-19. O "novo mundo" como já dado é o momento em que o mundo novo não precisa ser explicado, mas que a proposta de intervenção da Latam ajuda a configurar o investimento emocional que a marca quer buscar com o público. Assim, consideramos que o "novo mundo" em seu discurso publicitário faz parte de sua estratégia de mercado que é orientada ideologicamente, isto é, a Latam inventou um novo mundo para vender passagens, apesar da pandemia. 


\section{Referências}

BAKHTIN, M. M. O discurso no romance. In: BAKHTIN, M. M. Teoria do romance I: a estilistica. São Paulo: Ed. 34, 2015. p. 19-167.

BAKHTIN, M. M. O problema do texto na linguistica, na filologia e em outras ciências humanas. In: BAKHTIN, M. M. Estética da criação verbal. Tradução de Paulo Bezerra. São Paulo: Martins Fontes, 2011a. p. 307-337.

BAKHTIN, M. M. Os gêneros do discurso. In: BAKHTIN, M. M. Estética da criação verbal. Tradução de Paulo Bezerra. São Paulo: Martins Fontes, 2011b. p. 261-307.

BENVENISTE, E. Problemas de linguistica geral I. Coordenação de tradução de Eduardo Guimarães. Campinas: Pontes, 2005.

JENKINS, H. Cultura da convergência. Tradução de Susana Alexandria. São Paulo: Aleph, 2009.

LATAM AIRLINES. 2020. Facebook: Www.facebook.com/ LATAMBrasil. Disponivel em: https://bit.ly/3mFIRgm. Acesso em: 28 dez. 2021.

MEDVIÉDEV, P. N. O método formal nos estudos literários: introdução critica a uma poética sociológica. Tradução de Sheila Grillo e Ekaterina Américo. São Paulo: Contexto, 2012.

SANTOS, J. A. B.; BARONAS, R. L. Novo normal. In: INFORMA SUS UFSCAR. Enciclopédia discursiva da COVID-19. 2020. Disponivel em: https://bit.ly/3hZTUNM. Acesso em: 20 dez. 2020.

SOUZA, N. B.; MIOTELLO, V. Uma contribuição à crítica bakhtiniana: a(s) leitura(s) de Kisteva, o termo "slovo" e outros problemas em algumas traduções. Miguilim: Revista Eletrônica do Netlli, Crato, v. 8, n. 3. p. 545-562, set./dez. 2019

VOLOCHÍNOV, V. A construção da enunciação e outros ensaios. Organização, tradução e notas de J. W. Geraldi. São Carlos: Pedro \& João Editores, 2013.

VOLÓCHINOV, V. A palavra na vida e a palavra na poesia: para uma poética sociológica. In: VOLÓCHINOV, V. A palavra na vida e a palavra na poesia: ensaios, artigos, resenhas e poemas. Organização e tradução Sheila Grillo, Ekaterina Américo. São Paulo: Ed. 34. 2019. p. 109-147.

VOLÓCHINOV, V. Marxismo e filosofia da linguagem: problemas fundamentais do método sociológico na ciência da linguagem. Tradução de Sheila Grillo, Ekaterina Américo. São Paulo: Ed. 34, 2017.

\section{Agradecimentos}

O presente trabalho foi realizado com apoio da Coordenação de Aperfeiçoamento de Pessoal de Nivel Superior - Brasil (CAPES) - Código de Financiamento 001.

\section{Gabriella Cristina Vaz Camargo}

Mestra em Estudos da Linguagem pela Universidade Federal de Goiás - Regional Catalão (UFG/RC); graduada em Letras Português-Inglês; doutoranda em Linguistica e Lingua Portuguesa, pela Universidade Estadual Paulista - Campus de Araraquara (PPGLLP/ UNESP-FCLAr), em Araraquara, SP, Brasil. Membro do SLOVO - Grupo de Estudos do Discurso (UNESP-FCLAr). Desenvolve a tese com apoio da CAPES.

\section{Nathan Bastos de Souza}

Doutor em Linguística pela Universidade Federal de São Carlos (PPGL/UFSCar), em São Carlos, SP, Brasil; mestre em Linguística pela mesma instituição. Graduado em Letras com habilitação em Português, Espanhol e Literaturas respectivas pela Universidade Federal do Pampa (UNIPAMPA); Membro do Grupo de Estudos dos Gêneros do Discurso (GEGE/UFSCar). Professor substituto na área de Linguística e Língua Portuguesa na Universidade Federal do Pampa (UNIPAMPA), em Bagé, RS.

\section{Endereços para correspondência}

\section{Gabriella Cristina Vaz Camargo}

Universidade Estadual Paulista "Júlio de Mesquita Filho" - Campus Araraquara (SP)

Rod. Araraquara-Jaú, Km 1

Machados, 14800-901

Araraquara, SP, Brasil

Nathan Bastos de Souza

Universidade Federal de São Carlos

Rod. Washington Luis, km 235

Monjolinho, 13565-905

São Carlos, SP, Brasil

Os textos deste artigo foram revisados pela Poá Comunicação e submetidos para validação do(s) autor(es) antes da publicação. 